\title{
Teaching Reform and the Method of Interior Design for The Higher College
}

\author{
Huixia Zhen \\ Department of Environmental Art Design, Hebei Institute of Fine Art, ShiJiaZhuang HeBei, 050700, \\ China
}

123EEE@163.com

Keywords: indoor rendering, 3D design, teaching method.

\begin{abstract}
With the development of the social and economic, the demand for design professionals in the field of is diversified, therefore different levels, different types of talents will be welcomed by society. Interior design teaching should be established according to the environmental conditions of oneself and keep its teaching features, to design the teaching aim of talents cultivation, the specifications, should according to the diverse needs of society, a positive and creative response. Therefore, the hospital on the interior design teaching in applied talents for the characteristics of design teaching mode is given priority to, companies involved in curriculum design and project design. Colleges and universities such as interior design professional worker, arts and the sciences compatible. Especially its graphics teaching, engineering and arts two different directions, cultivate the students each have advantages and disadvantages. For partial and partial arts discussed different perspectives of interior design teaching, put forward with pertinence and maneuverability of liberal arts is compatible with the teaching ideas and concrete methods of teaching.
\end{abstract}

\section{Background}

Project teaching method of enlightenment in Europe early labor thought education reform period, its shape is the 18th century education majoring in education and in the 19th century in the United States and co-operation in Europe, after a long development course, it was not until the 20th century later period tends to WanShanHua slowly, become a kind of important theory and transition to the new trend. Project teaching mode is based on the industrial society and information society system forms of modern education. It to mass production and social unity as the main content, to the educates socialization, make educated to meet the requirements of modern productive forces and production relations as the main purpose, namely to cultivate practical talents for the society created a new model. In the project teaching method, learning process to become a creative social practice activities to one another, it pays attention to not only the final result, the more important is to complete the project process from the harvest. Students in the process of project practice to pay attention to the knowledge and skills to understand and grasp the course requirements, realize the innovation of hardship and joy, cultivate the ability to analyze and solve problems, eventually form a complete set of analytical thinking mode.

Interior design is the labor, the arts, the sciences compatible discipline, discipline span is big, the talents training target and way are different from other disciplines. To conform to the requirements of talents training target, teaching methods to meet the needs of professional development must be to study teaching system.

On the system, open interior design professional vocational colleges exists partial engineering and the arts. Partial engineering professional interior design based on a general engineering colleges and universities, the increase in the curriculum "engineering drawing", "housing architecture" and "engineering mechanics" engineering course, at the same time in teaching emphasize the standardization, operability, and safety. The quadrature in the compasses in colleges and universities graduates, field practice ability. Design scheme is compared commonly specifications, usually has a strong operability. But their design works of imagination and artistic appeal. Partial arts major general because art college offers interior design. On the teaching emphasis on "sketch", 
"color" the fine arts curriculum, emphasis on visual effect, creativity and imagination. This kind of university graduate student active float in the sky, full of passion. Design solution generally show a strong emotion and individual character, but in the normative and scheme of the figure of a slight lack of operability. Same profession has so different education effect, find out takes both advantages of a system should be set up interior design professional vocational colleges must be thought.

Interior design is a visual art design that is the core goal is graphics. Here graphics should cover engineering drawing, sketch, color, composition, etc. Interior designer by graphics to owner or the construction personnel to express their design intent. Therefore, research on teaching system should be put aside complex program later design theory and construction management, professional graphics system is emphatically discussed.

Interior design teaching should be to train in the design of the first line which has an independent design capability and can be engaged in the specific design and management of the design personnel as foothold, at the same time also should strengthen the noble moral character, to the human society sense of responsibility, has the innovative spirit and ability, have the consciousness and ability of lifelong learning, etc. The cultivation of the overall comprehensive quality. In higher education, the teaching quality is the life, school characteristics is an advantage. Key in interior design teaching reform pays special attention to the discipline characteristic, further to reform the course system and teaching content. In order to improve the teaching quality, fully meet the needs of the interior design teaching reform, the reform must be in the following aspects.

\section{First, the reform of the teaching mode}

On the teaching mode applied design talents as the goal of teaching mode, to cultivate the students' application ability is given priority to, emphasis on cultivating students' professional design ability, comprehensive design ability, innovation ability, to adapt to the social demand and the development of The Times. Interior design teaching should be to train in the design of the first line which has an independent design capability and can be engaged in the specific design and management of the design personnel as foothold, at the same time also should strengthen the noble moral character, to the human society sense of responsibility, has the innovative spirit and ability, have the consciousness and ability of lifelong learning, etc. The cultivation of the overall comprehensive quality.

Engineering graphics teaching commonly used engineering teaching content. Teaching emphasis on abstract logical thinking ability and mathematical relationships. Lectures in the traditional model of teaching methods used more concentrated. Teaching practice has the uniformity, the answer is more stringent standards. The regular teaching program is: teaching, demonstration, practice and commented. This kind of teaching pattern from beginning to end all to carry out the strict logical science technology, scalability, and progressive. Students can in the system of teaching rigorous work habit and standardized graphics expression [1]. The teaching of engineering graphics in descriptive geometry, the theoretical basis of the three view drawing as the main expressive means. Starting point, line and plane projection, to the study of geometry superposition, dig form and the three-dimensional cutting, plane projection reversal form complex three-dimensional space concept. Drawing standards its core purpose is to develop accurate $3 \mathrm{~d}$ space imagination and standardized view, drawing ability; Three view drawing and axonometric drawing is its core content of repeated interactions. The effect of forming in your mind quickly and standard three-dimensional imagination, and with AutoCAD drawing tool or means of computer aided accurately express the design intent; At the same time form a rigorous and normative logic thought [2]. Engineering graphics recognition and its production of uncertainty is in the process of training must be strictly observed. The correctness of the graphics, can be used in the production of machining is the ultimate goal, under the size specification only has practical significance.

Arts graphics teaching generally follow the traditional pattern of art colleges, after the system theory is introduced based on the principle of correlation, for example, to visual image thinking to guide students thinking, give students leave a large space. If on a subject, first to formulate goals 
and objectives and the final form, students can according to the requirements of the teacher mentioned target to implement, and any method. Finally the teacher by focusing on commented give direction and the guidance of the principle. Free space of this model to students and to the beginning ability, expression ability cultivation of graphic art on the basis of the sketch, color, combination of plane composition, color composition, three-dimensional construction of theoretical basis, with dot, line, face and all kinds of color for the element, the research on the rules of the combination of graphics, change and unity as its core. Various elements is a means of emotion or intent and symbols. Designers through the basic skills of freehand drawing or plane computer-aided design software like Photoshop to express themselves on visual design change process; Exercise at the same time up to the standard of aesthetic imagination and creativity [3]. Art graphics is outpouring of emotion, is to achieve the ultimate goal of the visual enjoyment, and size and drawing specification into bondage thinking factors here.

\section{Second, the reform of the teaching method and teaching content}

For teachers and schools, interior design teaching and practice should be adapted to today's design market changes, we need to constantly thinking and study design teaching reform, build a set of take the market as the backing, take the student as the main body, establishing scientific personnel training mode and curriculum system, to adapt to the demand of the society.

Strengthen the training of the basic knowledge, grasps the reasonable knowledge structure

Develop the students' ability of design need solid basic skills. Basic knowledge should be combined with professional knowledge, training students to the object of observation ability, expression ability, memory ability, aesthetic ability, develop their spirituality, cultivate their divergent thinking mode, reasonable knowledge structure is very important for a designer, because basic knowledge is an integral part of the overall knowledge structure. Design create presentation skills including a variety of ingredients, its knowledge structure includes not only the necessary professional knowledge, but also including philosophy, sociology, ethics, psychology, aesthetics and information science knowledge.

According to the above requirements, the interior design course on the content setting by profession needs to be adjusted, in addition to the traditional rendering techniques training, also add on3dmax, AutoCAD and other professional software, such as teaching content, some of the course content need to adapt to the current trend, such as residential space design ShiYingFang real estate development and the change of the people to live idea, combined with today's interior design decoration and assembly features, increase the students' appreciation of furniture, furnishings and environmental greening the aspects of curriculum content. Considering the need of the development of computer technology and professional learning, to open the AutoCAD, curriculum content and so on3dmax, focusing on the training of the professional drawing software. According to unit of choose and employ persons, the many graduates are lack of the understanding of materials and their structure, lead to deviation between design and actual construction, therefore, the material and construction as an important design skills class content included in the teaching, strengthen students' ability of cognition and application of materials.

\section{Pay attention to training students' practical ability}

Practice ability including the ability to model making, computer aided design. American art design education on the arrangement of the course, students' practice and part accounted for more than eighty percent, visible to develop students' manipulative ability of practical value. Some developed countries in art design teaching and curriculum difference is very big, but have one thing in common, is all attach great importance to the course and practice course of technology study, emphasize the cultivation of the students practical ability.

\section{The emphasis on the cultivation of students creative thinking}

The essence of art design is to create. A good design is often effective bright ideas, and good ideas are the designer of creative thinking and flash. Art and design have no standard mode, no common standard, also have no unified the answer, but to make public individual character and creativity as its characteristics. Creativity is the life of art and design. New and novelty and 
personalized design. Whether it is interior design, fashion design, product design, advertising design, and visual communication, etc., without exception. The never-ending pursuit of innovative creativity, a brand-new visual impact, is the basic characteristics of art and design. So the art design education emphasizes to create consciousness and the cultivation of creative thinking and training, think beyond the existing and development as a constant belief. Emphasis on into the thick of life, cultivating practical talents. Art design is a kind of art reality, compared to pure art, closer to the society, and close to people's life. Life can only into the thick of life, good at observation, to create a design conforming to the requirements of the society.

The application of teaching software interior design course teaching on the application of computer drawing software, such as the United States Autodesk company production soft ware 3 dmax and AutoCAD software, are commonly used drawing software, each big, companies, art colleges in our country most enterprise applications. It has a rich and powerful mapping, graphics edit, display control, graphical output, and other functions, can be used for each major. Introduced all kinds of books also is very rich, and with strong three dimensional function and secondary development function, it can help students in specialized courses and graduation design of the study and application to lay the foundation. Computer drawing teaching focuses on the basic concept, function, operating process and matters needing attention of each command, application situation, comparing image intuitive, traditional teaching methods have been unable to meet the needs of computer drawing teaching, in the room with modern multimedia teaching method is more suitable for the teaching of computer graphics. It is compared with that in ordinary classroom has the following advantages: first, intuitive, image to impart knowledge. In the multimedia computer teaching, can put each command step by step, the concrete operation process and matters needing attention to speak clear and thorough. Second, can improve the teaching effect. In the multimedia computer teaching, the teacher can make the contents of teaching courseware in advance, direct call in class, there is sound, animation, effect is very good, but also save the writing blackboard writing, such as clean the blackboard. So that we can make the students save more time to practice, is more advantageous to grasp of the software application. Once again, can improve the quality of teaching. In multimedia computer teaching, can make the teacher lectures and practice with environment, the content of the teacher has just finished, students will practice on computer, so the theory teaching and practice together, facilitate students grasp the knowledge more effectively, improve the quality of teaching.

In teaching can guide students to foster strengths and circumvent weaknesses, interactive software use and comprehensive use. For example, in drawing interior design renderings, comprehensive mapping can take the following steps.

(1) using AutoCAD drawing plan; (2) will be painted floor plan into 3 on3dmax, three-dimensional after paste material, lighting and rendering Settings; (3) use Photoshop to add various configuration and color rendering deployment and other artistic processing. These steps linked together, and gradually formed the stylization, made up for their shortcomings, yet to create the better effect.

\section{The renewal of the teaching concept}

As an organizer of teaching activities, teachers should first strengthen their own professional learning theory, at the same time of constantly update their professional knowledge and actively absorbed what is advanced in other excellent teachers in teaching method, to inspire and create more suitable for the course teaching, can stimulate students interest in learning class situation, finally realize the optimization of classroom teaching achievements. Change the teaching method, in view of existing different status of students, design can fully mobilize students' learning initiative, music teaching between teachers and students happy classroom environment; On the design of the class situation focus on starting from the actual student life, highlight the form of novelty, practicality and method the content of the inspiring, so that students from passive audience role as active participants. For example, I be being designed indoors,

Data teaching about the simple to the characteristics of the introduction of the knowledge of human body engineering is particularly important for the understanding of it will help students 
understand with human body measure as the benchmark for industrial products and the importance of reasonable design, the interior space at the same time also is to let students know the importance of art and human life closely related. For this purpose, the furniture in the course of human body measure, to bring the student to carry on the market research, the furniture of brand on the market at present, price, material, technology, structure design and so on have intuitive feelings and system, back to the classroom to carry on the design again. In the teaching process, causes the student to obtain more comprehensive information through mutual communication, improve the students' ability to design.

\section{Third, strengthen the foundation and the teaching of theoretical knowledge}

1) in the interior design curriculum teaching, the basic knowledge teaching and theory teaching is the foundation of the whole teaching, is a key link in the teaching. When undertaking interior design teaching, pay attention to basic knowledge and theory of knowledge teaching, build the foundation of knowledge structure, lays the foundation for the interior design of the whole study. Interior design is a strong comprehensive discipline, as well as a cross subject, involves many fields, such as art, aesthetics, architecture, and materials science are linked. The edge of the interior design as a comprehensive discipline, the accumulation of basic knowledge and theory knowledge is very important. Interior design teaching, need to start from basic knowledge and theory knowledge teaching, to indicate the development direction of interior design teaching. Pay attention to basic knowledge and theory of knowledge teaching, not only in a definite degree make up for the insufficiency of the traditional teaching mode, but also for the interior design teaching reform provides a effective way.

2) improve and expand the administrators and teachers' professional knowledge level of teachers is the fundamental education, and teachers' professional quality directly affects the teaching effect. Improve the professional quality of teachers, be helpful for the completion of tasks of teaching efficiency and teaching, more can develop the students' comprehensive quality and ability, and cultivate more excellent talents. Teachers must have good professional knowledge level, knowledge should not stay in preparing a class lecture stage, also should not pay attention to basic knowledge and theory knowledge teaching, teachers should adapt to the development of The Times, constantly update their knowledge structure, to accept and absorb the advanced teaching ideas, improve the quality of teaching. Teachers to update their knowledge structure, but also to adapt to the development of The Times, the teaching idea and teaching model also must carry on the reform and innovation. In the colleges and universities teaching, to build a branch of high-quality talent team of teachers, to rise the teaching quality, better room The design course teaching. Is a straight in a constantly changing market, teachers only constantly enrich himself, update their ability to meet the needs of times development, in order to cultivate excellent talents. Improve teachers' professional knowledge level, is not only beneficial to the improvement of teaching efficiency and teaching effect, also can help students better adapt to rapidly changing market, improve the students' employment rate.

3) establish proper talents cultivation target and the main teaching body interior design course teaching goal is to train talents with good professional quality, to some extent this highlights the talents' training goal. Employment oriented to establish talents training target, helps to cultivate qualified personnel to interior design, to improve students' employment rate.

Develop talents training target, teaching activities carried out on the one hand to revolve around employment as the guidance, on the other hand also should pay attention to build a sound teaching system establishing and perfecting the system of course teaching, based on project integration of teaching practice, knowledge and theoretical knowledge to improve students' ability to master in jobs. College teachers in the interior design teaching, pay attention to guide students to set up the correct outlook on life and values, cultivate students for jobs love emotion, improving students' comprehensive quality and ability. 


\section{Fourth, strengthen the combination between production practice teaching}

Production in combination with the practice teaching is a basic approach to cultivate practical talents, the teaching process focuses on the mastery of competencies at design and the cultivation of basic skills. Practice teaching can make students focus on the latest situation of the social practice, the contents of professional study closely combined to solve practical problems, truly reflects the theory with practice, let students to practice, improve graduates work ability to adapt. This clearly reflected in the project design of the teaching, thematic design mainly cultivate students for design object, based on various design constraints, to find the best solution. When designing task training content and form, to choose design company or reconstruction projects as the training objects. Training form mainly adopts real topic real done, virtual topic real done two forms. Real topic real done is to put the design project of the various restrictions as to the specific requirements of the selected topic, the reference design workflow and complete the requirement of design problem of the company. Request to track the teaching design company, to student's design proposal, let the students have the opportunity to further design the first line, be familiar with design works of the company. Virtual real do is put the design of the virtual subject in real environment to carry on the design of this kind of topic generally belongs to the redevelopment project, students can conduct site survey, to understand and explore limit design conditions. This method between virtual and reality, in dealing with all kinds of restriction conditions at the same time, students and larger space for the subjective performance, which is very attractive for students. Two forms of training, there is a common feature, is the emphasis on the authenticity of the training subject. Specific environment to carry out the design must be based on reality, and design company involved in increasing the effectiveness of training process, can let students feel some is only to be learned in the field environment of important industry norms, conscious experience and strain method. Use of university-industry cooperation, emphasis on ability training teaching method is not only widely used in the project design course teaching, such as graduation design requires the ability to reflect the comprehensive design course can also be used.

An important link in training practical ability is the design of field research and analysis, students according to their abilities and preferences to select the suitable design object, through the in-depth design of the field investigation, discover and capture one of the effective information, such as site conditions, user characteristics, use function requirements, etc., make it become the starting point for design and put forward the basis of a solution. Interior design course is rich in content, flexible teaching ideas and characteristics of thematic, and should not be restricted teaching field and region; Project design forms, can reflect and reflect the reality of the city, the organic combination of classroom teaching and field teaching, to cultivate students to design the site observation ability, analysis ability and sensitivity.

\section{The project teaching method and interior design}

The body of the interior design courses set up in interior design and decoration for the overall framework, it was based on the theory combining with practice and improve the ability of a professional course in practice. Just around professional jobs on the talent requirements, form a complete set of project in the required basic knowledge, practice ability and basic quality and structure of the teaching design. According to the concrete operation process of the project, the early stage of the theory of teaching, on the basis of this theory to the practice, the first class in the production line, close to the practice, students learned knowledge not divorced from reality, to demand for the purpose of vocational and technical education, employment as the guidance, the combination of education idea, so as to achieve the purpose of use. In general, the traditional interior design professional teaching model is based on the industry in the development of the society demand and set up corresponding to the professional course. [4] Combined with the content of the course and the course of the professional component set hours; For professional teachers to examine the system training and on-the-job, excellent teacher allowed to teaching, the main way to multimedia presentation, on-site demonstration, interactive teaching mode such as answering 
questions; In the final endgame, to student's class performance at ordinary times and final written examination result, the combination of to draw students' comprehensive performance; In the process of the implementation of the teaching, the parallel type, the number of courses each semester, according to the different nature of the course, successive finish the teaching task; After school, average score statistics departments, eligible to allow concurrent graduation diploma and degree certificate. Along with society of interior designers are increasingly demanding social practice ability, the traditional interior design teaching mode can not meet the current social demand for talents, so a new teaching model and design concept of organic combination become the new trend.

The traditional interior design teaching mode the following deficiencies:

a. consciousness of students is relatively slow;

b. professional interest in difficulty;

c. evaluation system practicality is not strong, the one-sided focus on the theory;

$\mathrm{d}$. the teaching schedule is not flexible, professional skills learning continuity is poor, not solid skills mastered,

e. teaching material used is not flexible, professional training is relatively rigid. To change the status quo, the introduction of new teaching methods and the use is an important means to make up the shortfall.

If the project teaching method is applied to the interior design of the course, not only can effectively make up for the inadequacy of traditional teaching, but also meet the requirements of the ability of society for talents.

Project teaching method advantages:

a. improve the students' learning interest, arouse the enthusiasm of students learning. Project teaching method is to let students independently or in a team situation is a specific project. As compared to the classroom, the project practice content is relatively flexible, time is relatively loose, provide students creativity and imagination of space, enhanced sense of teamwork, a clear division of responsibilities and refinement, to enhance the work efficiency. Students not only to find and solve problems in the process of the growth of knowledge, experience and more hardship and joy behind successful results.

b. solved the problems of book centered teaching. Project teaching method for students' autonomous learning space, teachers can guide and assist in the process of project implementation, students found that the problem itself, ego problem solving, learning enthusiasm and initiative into full play, time is relatively loose, greatly improve the students' learning efficiency, and constantly found insufficient, in turn, improve skills, from practice to grasp skilled.

\section{Project teaching method in the application and development of interior design training course}

Higher vocational education is training practical personnel in the first line of production and social practice, and through many years of higher vocational professional interior design interior design in the process of teaching, found that most operating guidance as interior design professional courses, if only to follow the theory teaching and practice teaching mode, it is hard to cultivate construction technical management personnel. Therefore, the new teaching method in the application of the training course will be the key to solve their problems. [5]

The introduction of project teaching method concept, can make indoor design professional teachers' teaching and students' learning have clear objectives, improve the learning efficiency. Students through the course of design should be able to resolve the space function, environmental art, and a series of practical engineering problems. Therefore, the project teaching method in the concrete practice of interior design course should be divided into the following steps:

a. into the project. Students are required to actual design within the prescribed period of time to complete the project;

b. make a plan. Each student according to the practical goals and tasks of the project, make full use of the equipment and other resources to develop project plan, determine the steps and procedures of work, under the guidance of teachers, the final confirmation after analysis; 
c. implementation of the project. After the student in determining the scheme, according to the project plan to select the group leader, divided into several groups to begin the implementation of the project;

e. show. Project completed, make the finished product, to display;

f. assessment. Teachers according to each student participation in the process of the whole project, the role of, cooperation ability and the final results of design works display and so on carries on the comprehensive evaluation;

g. outstanding works to give praise and encouragement, less work analysis, pointed out problems, and to give correct.

About the reform of teaching, the author put them into teaching practice, practice test these ideas are effective, improve the students' professional skills. Due to the closer to the actual course content more concise, method of teaching students more easy to accept; Practice project combined with the multimedia teaching, and the case analysis, targeted follow the market development, cooperate with landscape practice, improved the students' learning enthusiasm, also added a employment channels. Of course, these measures still need to improve, the exploration of teaching reform will continue. In order to improve the quality of education, interior design must be under the guidance of spirit of innovation, change of teaching, all-round, multi-angle exploration, from the requirement of social development of talent quality interior design, to establish perfect interior design teaching system. With the development of the era and the continuous improvement of the economic market system and send to the more intense market competition, only good people can place in the fierce market competition. In the interior design teaching, to reform the teaching methods, improve the level of teachers' professional knowledge, establish proper talents training target and curriculum system, at the same time in the make up the shortages of the traditional teaching way, the way of teaching reform and innovation, improve teaching efficiency and teaching effect to cultivate the comprehensive high-quality talents, so as to adapt to the fast development of the market.

Pay attention to teaching mode of exploration and innovation, foster strengths and circumvent weaknesses, create characteristic, pay attention to the interior design teaching method improvement, constantly improve the quality of teaching, make interior design teaching adapted to the development of The Times.

\section{References}

[1] Ma Jian-mei. Environmental art course teaching mode reform of professional landscape design [J]. Anhui Agricultural Science. 2011 (31)

[2] Tang Jun. The development of modern landscape design present situation and trend analysis [J]. Chinese Gardening Abstract. 2012 (9) : 97-2012.

[3] Han Yu. Experience type teaching, the landscape design course teaching practice research [D]. Nanjing: Nanjing College of Art. 2012

[4] Suo Liya. The exploration and research of "project engineering room" in the teaching of interior design specialty in Higher Vocational colleges. Journal of Chongqing Education College. 2012 (6): 127-128

[5] Wang Lijiong. On the teaching reform of interior design studio teaching in Higher Vocational education. Jiannan literature. 2012 (7); 294-295 